\title{
Signal transducer and activator of transcription 5 as a key signaling pathway in normal mammary gland developmental biology and breast cancer
}

\author{
Priscilla A Furth ${ }^{* 1-3}$, Rebecca E Nakles ${ }^{\dagger 1}$, Sarah Millman ${ }^{+1}$, Edgar S Diaz-Cruz ${ }^{\dagger 1}$ and M Carla Cabrera ${ }^{+1}$
}

\begin{abstract}
STAT5 consists of two proteins, STAT5A/B, that impact mammary cell differentiation, proliferation, and survival. In normal development, STAT5 expression and activity are regulated by prolactin signaling with JAK2/ELF5, EGF signaling networks that include c-Src, and growth hormone, insulin growth factor, estrogen, and progesterone signaling pathways. In cancer, erythropoietin signaling can also regulate STAT5. Activation levels are influenced by AKT, caveolin, PIKE-A, Pak1, c-Myb, Brk, beta-integrin, dystroglycan, other STATs, and STAT pathway molecules JAK1, Shp2, and SOCS. TGF- $\beta$ and PTPN9 can downregulate prolactin- and EGF-mediated STAT5 activation, respectively. IGF, AKT, RANKL, cyclin D1, BCL6, and HSP90A lie downstream of STAT5.
\end{abstract}

\section{Overview of the STAT5 signaling node in mammary epithelial cells}

Signal transducer and activator of transcription (STAT) 5A and STAT5B are members of a well-known group of transcription factors [1-3]. STATs were first identified as members of a non-tyrosine kinase-containing cytokine receptor-activated signaling pathway [4]. There are seven identified components of the STAT transcription factor family: STAT 1 to 4, 5A, 5B, and 6. STAT5A and STAT5B are closely related family members thought to be a result of gene duplication $[1,5]$. During normal mammary gland development, STAT5A plays the more prominent role [6-10], whereas both STAT5A and STAT5B have been described as contributing to breast cancer pathophysiology

${ }^{+}$Contributed equally.

*Correspondence: paf3@georgetown.edu

'Department of Oncology, Lombardi Comprehensive Cancer Center,

Georgetown University, 3970 Reservoir Road NW, Research Building, Room 520A,

Washington, DC 20057, USA

Full list of author information is available at the end of the article
[11-17]. After interactions of cytokines, hormones, and growth factors with their respective cell surface receptors, STATs are activated, primarily by phosphorylation at tyrosine residues, and then dimerize and translocate to the nucleus. Once in the nucleus, STATs can initiate gene transcription [2]. The activity of STAT proteins can be influenced by serine phosphorylation [18], regulated dephosphorylation [19], and interactions with cellular proteins, including adhesion and basement membrane molecules. In mammary epithelial cells, the STAT5A/B (STAT5) pathway modulates three different cellular outcomes: differentiation, survival, and proliferation (Figure 1). The two STAT5 proteins, STAT5A and STAT5B, can homodimerize and heterodimerize. The relative impact of STAT5 on the three different cellular outcomes varies in normal as compared with malignant mammary epithelial cells as well as between different types of normal and malignant mammary epithelial cells.

In mammary epithelial cells, STAT5 can be activated through a few different and sometimes interacting signaling pathways (Figure 2). Many of the pathways that mediate normal development and lactational differentiation (Figure 3) also regulate STAT5 activation in breast cancer cells (Figure 4) but with a few distinctions. Janus kinase (JAK) 2, a tyrosine kinase, is a key signaling node for STAT5 activation in both normal and malignant mammary epithelial cells $[17,20,21]$. In normal mammary epithelial cells, this is predominantly mediated through prolactin (PRL) acting through the PRL receptor (PRLR) upstream of JAK2/STAT5 [22-25]. Interestingly, in breast cancer cells, JAK1 activation through a PRLR-JAK2 interaction can enhance STAT5 signaling [26]. Human cellular-Src (c-Src) is a second key signaling node for STAT5 activation in normal and malignant mammary epithelial cells. Loss of c-Src interrupts STAT5 activation during pregnancy, and in malignant cells c-Src has been shown to mediate STAT5 activation downstream of estrogen/estrogen receptor-alpha $(E R \alpha)$ and epidermal growth factor (EGF) signaling and to contribute to activation through the PRL/PRLR/JAK2 pathway [4,16,27-29]. One example of the impact of these 


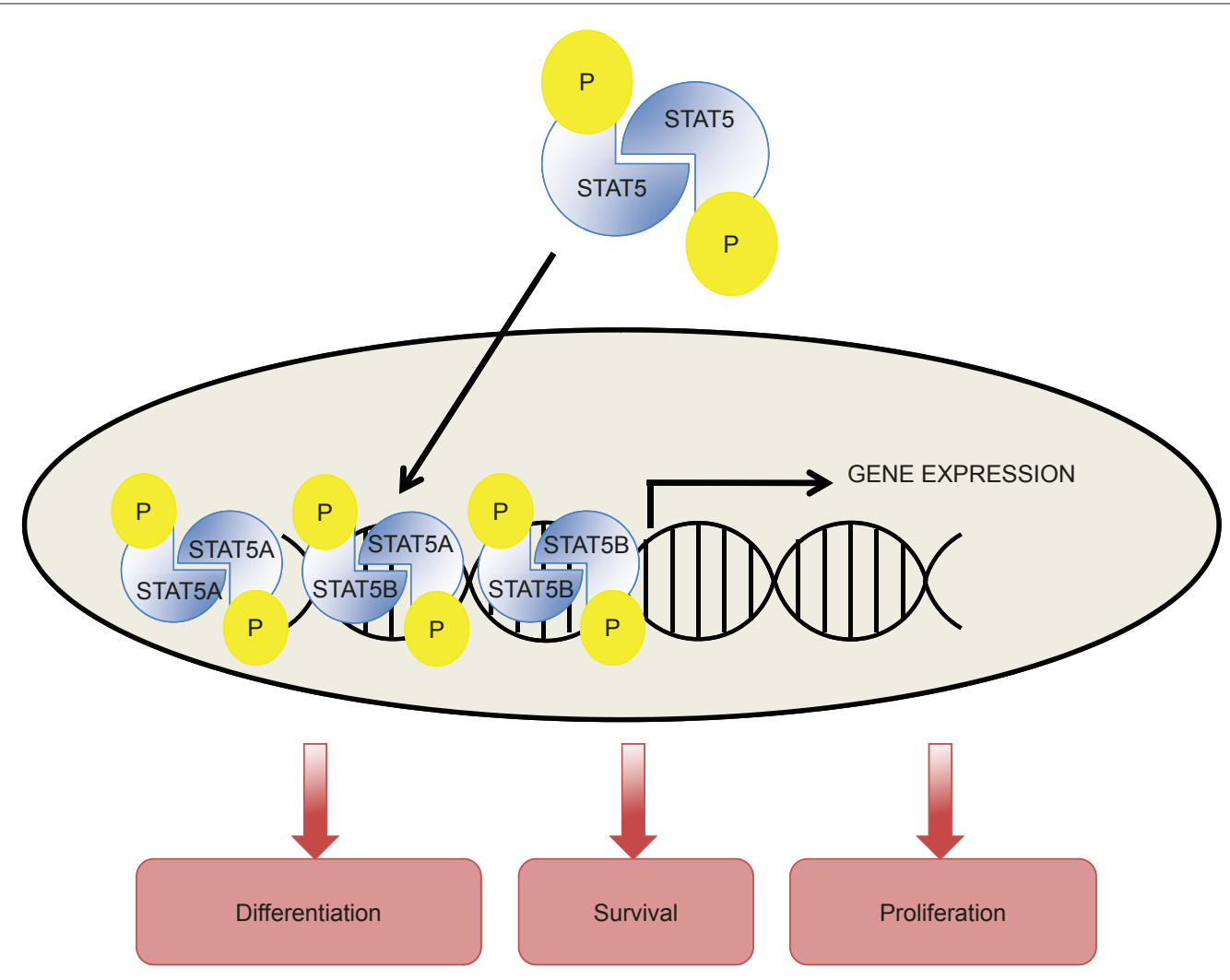

Figure 1. STAT5 influences differentiation, survival, and proliferation through alterations in cellular gene expression. After activation by tyrosine phosphorylation (P), STAT5A and STAT5B form homodimers and heterodimers that move into the nucleus, where they can act as transcription factors to influence gene expression. STAT5, signal transducer and activator of transcription 5.

interacting signaling nodes is shown by the dual activation of STAT5 by estrogen and EGF [28]. When activated by estrogen in breast cancer cells, STAT5 requires c-Src and EGF, but if the EGF receptor (EGFR)/ c-Src pathway is hyperactivated, the responsiveness to changes in the estrogen pathway activation is altered and this can contribute to the development of endocrine therapy resistance. A second example lies behind the deleterious effect of recombinant human erythropoietin ( $\mathrm{rHuEPO})$ on the sensitivity to trastuzamab in breast cancer cells [30,31]. Trastuzamab is a monoclonal antibody that targets the human EGFR 2/Neu receptor, an important growth stimulus for a subset of breast cancers. Resistance to trastuzumab occurs when rHuEPO stimulates JAK2, leading to the activation of both c-Src and STAT5. In normal mammary epithelial cells, growth hormone (GH) acting through the GH receptor and JAK2 can activate STAT5 [32]. The EGFR and ErbB4 - or verb-b2 erythroblastic leukemia viral oncogene homolog 4, neuro/glioblastoma-derived oncogene homolog (avian) - are reported to directly associate with and activate STAT5 in mammary epithelial cells [33-35]. The IGF pathway plays an important role in STAT5 activation in mammary epithelial cells, and signaling through the IGF receptor can be processed through the JAK/STAT pathway [36].

Activity of the STAT5 pathway in mammary epithelial cells is also regulated at the level of STATSA and STAT5B gene expression. Expression levels can be modified by changes in the activity of estrogen and progesterone signaling pathways [37-39] and by either EGF or IGF stimulation [40,41]. E74-like factor 5 (ets domain transcription factor) (ELF5) appears to modulate both expression levels and activation of STAT5, perhaps through changes in expression levels of suppressor of cytokine signaling (SOCS) family members [42].

Protein-protein interactions between STAT5 and other cellular proteins are able to modify STAT5 action. One class of protein-protein interactions in mammary epithelial cells is between STAT5 and the nuclear hormone receptors expressed in these cells, including $\mathrm{ER} \alpha$ [43-45], progesterone receptor (PR) [46], and glucocorticoid receptor [7,47-50]. Other cellular proteins that have been shown to impact STAT5 activity include PI 3-kinase enhancer A (PIKE-A) [51], serine/threonine protein kinase Akt (AKT) [52], p21-activated kinase 1 


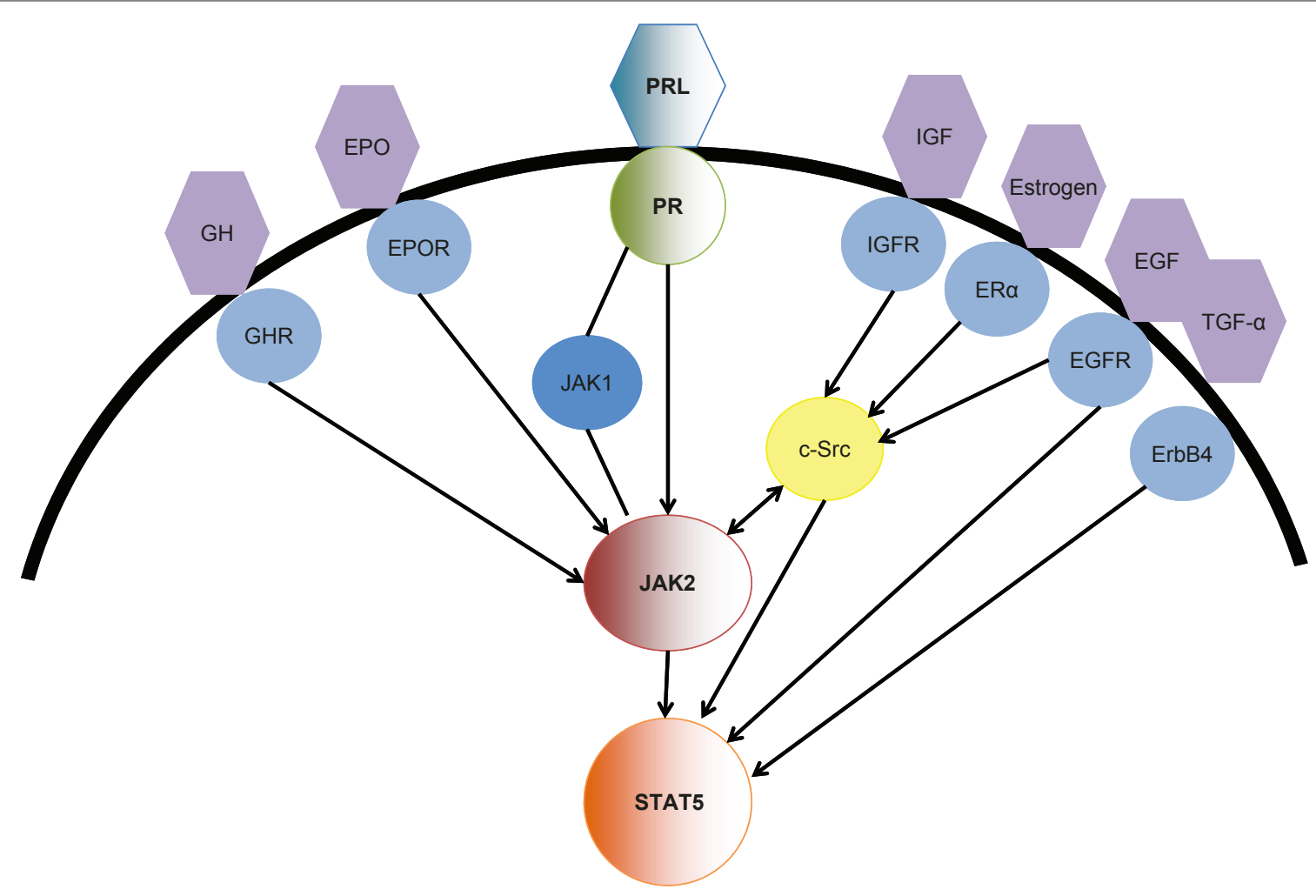

Figure 2. STAT5 can be activated by diverse and sometimes interacting signaling pathways in mammary epithelial cells. Prolactin (PRL) signaling networks dominate in STAT5 activation in normal mammary gland development with contributions from growth hormone (GH), insulin growth factor (IGF), estrogen, epidermal growth factor (EGF), and ErbB4 signaling. PRL and GH work predominantly through their respective receptors prolactin receptor (PR) and growth hormone receptor (GHR) through Janus kinase 2 (JAK2) and are key mediators of pregnancy-induced mammary gland development. Estrogen and EGF acting through respective receptors estrogen receptor-alpha (ERa) and EGF receptor (EGFR) initiate pubertal mammary gland development and contribute to pregnancy-induced development. They can interact through human cellular-Src (c-Src) pathways. Transforming growth factor-alpha (TGF-a) is the second ligand from the EGF family to be shown to influence STAT5 activation levels in normal and cancer cells. IGF signaling through insulin growth factor-related receptors (IGFRs) may also include c-Src and, under some circumstances, JAK2 in both puberty- and pregnancy-induced development. The contribution of ErbB4 to STAT5 signaling is most prominent during lactation. In breast cancer, EGF and estrogen pathways acting through c-Src can drive proliferation and survival. JAK1 has been shown to increase PR/JAK2 activation in some settings. When the erythropoietin receptor (EPOR) is expressed in breast cancer cells and erythropoietin (EPO) is present, they can signal through JAK2 to STAT5 to promote resistance to trastuzumab therapy. ErbB4, v-erb-b2 erythroblastic leukemia viral oncogene homolog 4, neuro/glioblastoma-derived oncogene homolog (avian); STAT5, signal transducer and activator of transcription 5.

(Pak1) [18], the transcription factor proto-oncogene v-Myb myeloblastosis viral oncogene homolog (avian) (c-Myb) [53], breast tumor kinase (Brk) [54], and caveolin [55].

STAT5 has been shown to have a role in controlling the activity of factors that can contribute to its own activation. STAT5, particularly STAT5B, has been shown to regulate IGF levels in mammary tissue and liver [12,56-58]. A feedback loop through SOCS molecules has been suggested as a mechanism to regulate the IGF/ STAT5 signaling axis [36]. As reported above, ELF5 increases expression levels of STAT5. It was also reported that increasing STAT5 expression levels increases ELF5 expression levels [59].

The impact of STAT5, a known transcription factor, on the cell lies, at least in part, through regulation of gene expression. During lactation, STAT5 activation contributes to the high expression levels of milk protein genes. STAT5 activation also has been linked to regulating expression of the cell cycle control protein cyclin D1 both directly and indirectly $[12,15,16,51,60-62]$ and expression of receptor activator of nuclear factor-kappa-B ligand (RANKL) [62,63]. Significantly, changes in STAT5 expression and activity can also modify the expression and activity of other STAT family members, most prominently STAT3 $[60,64,65]$. These changes in STAT3 expression or activity then can modify gene expression patterns as a secondary effect.

In summary, STAT5 can be activated by different and sometimes interacting signaling pathways in mammary epithelial cells. The prolactin, EGF, estrogen, GH, and 


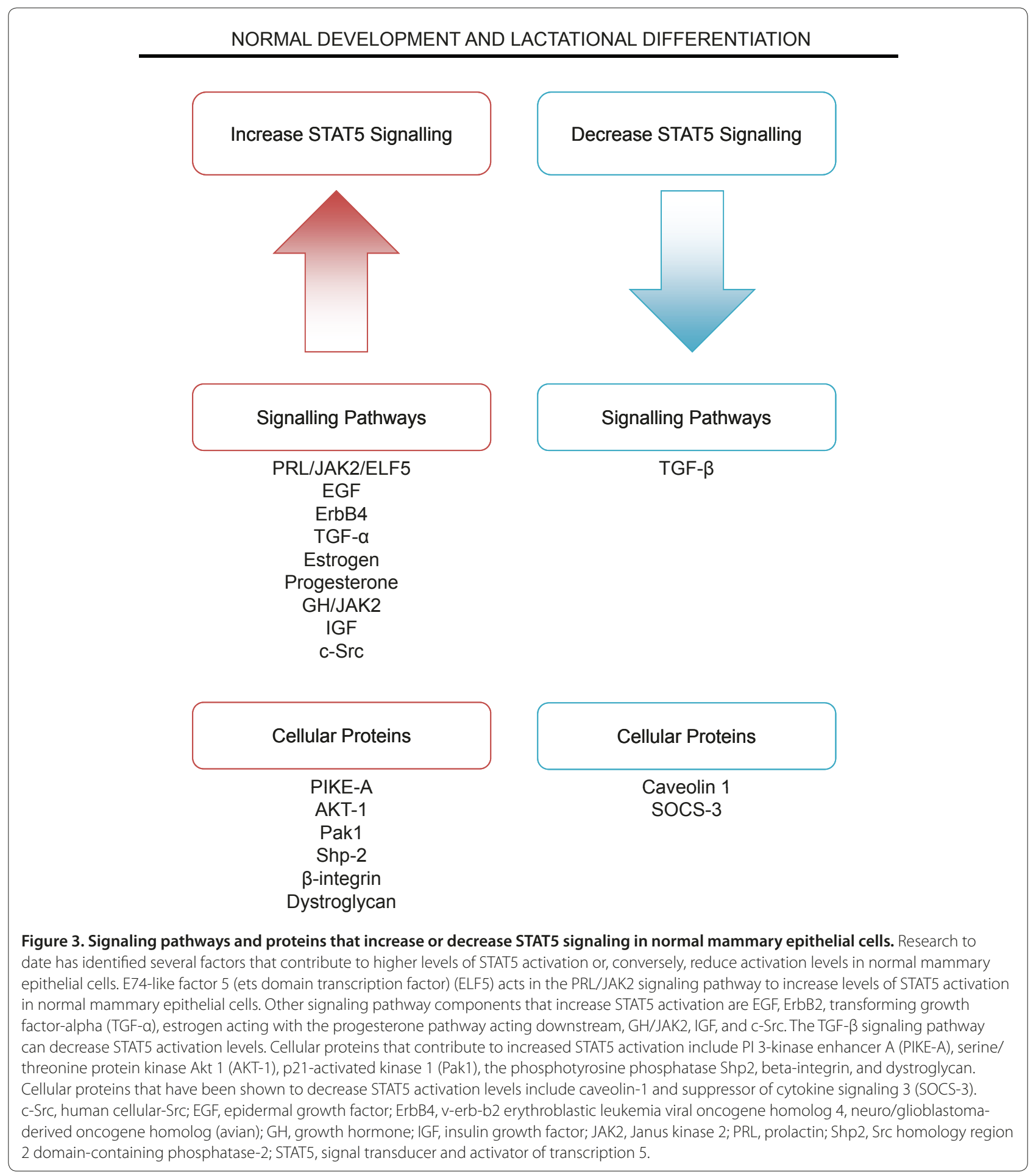

IGF pathways are well-established regulators of mammary epithelial cell behavior in both normal and malignant mammary epithelial cells. The erythropoietin (EPO) pathway is a more recently recognized signaling pathway in malignant mammary epithelial cells. In addition to being regulated by activation through tyrosine phosphorylation, STAT5 activity can be regulated at the level of gene expression and a number of protein-protein interactions have been shown to influence its action. Downstream gene expression changes are thought to 


\section{BREAST CANCER CELLS}
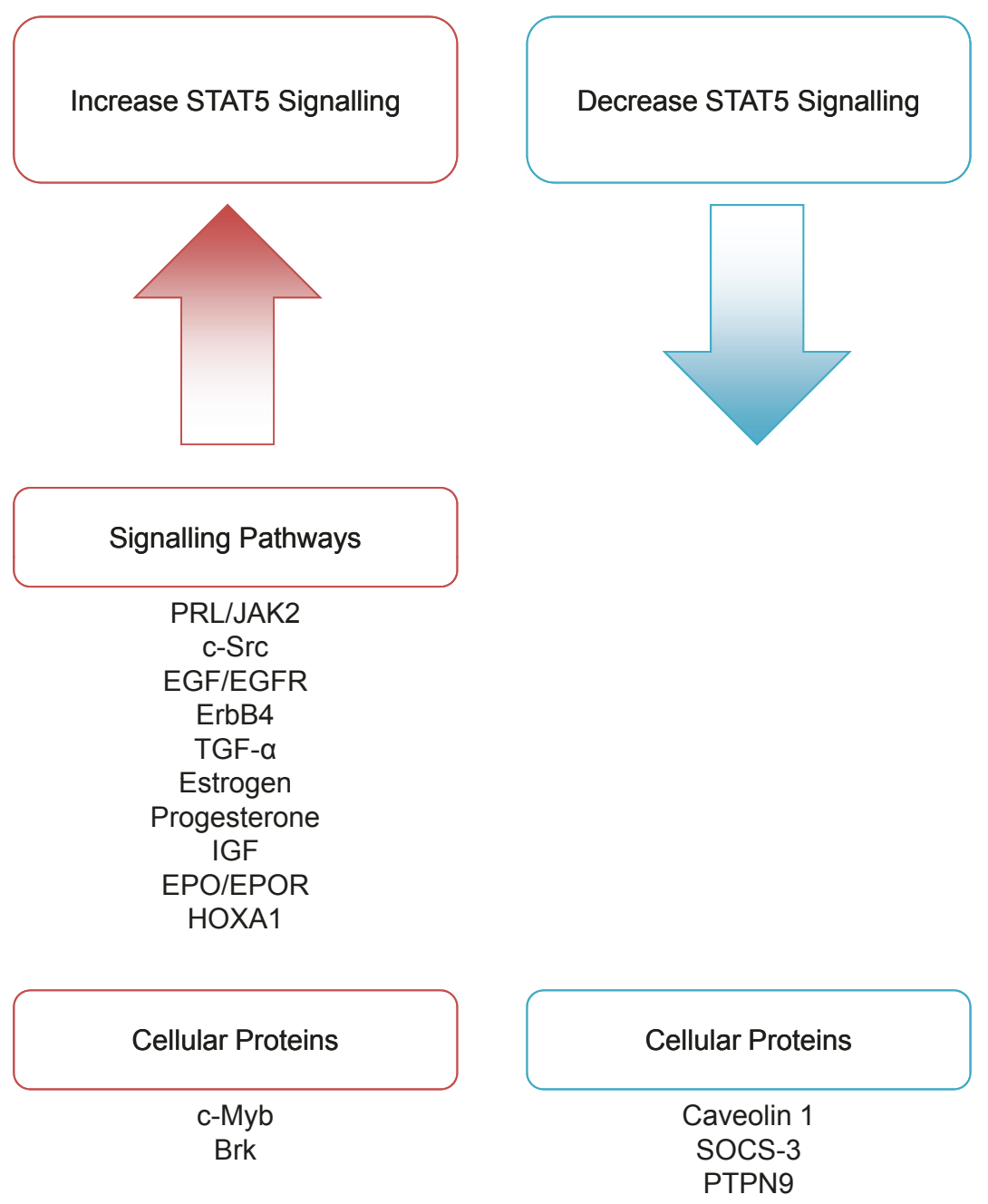

Figure 4. Signaling pathways and proteins that can increase or decrease STAT5 signaling in breast cancer cells. Research to date has identified several factors that can contribute to higher levels of STAT5 activation or, conversely, reduce activation levels in breast cancer cells. As in normal mammary epithelial cells, PRL/JAK2, c-Src, EGF/EGFR, ErbB4, TGF-a, estrogen and progesterone, and IGF pathways can increase STAT5 activation. In breast cancer cells, EPO/EPOR and HOXA1 also have been shown to increase STAT5 signaling. Two cellular proteins shown to increase STAT5 activation in breast cancer cells are breast tumor kinase (Brk) and transcription factor proto-oncogene v-Myb myeloblastosis viral oncogene homolog (avian) (c-Myb). As in normal mammary epithelial cells, caveolin-1 and SOCS-3 can downregulate STAT5 activation; however, in breast cancer cells, PTPN9 (protein tyrosine phosphatase, non-receptor type 9) also has been shown to downregulate STAT5 signaling. c-Src, human cellular-Src; EGF, epidermal growth factor; EGFR, epidermal growth factor receptor; EPO, erythropoietin; EPOR, erythropoietin receptor; ErbB4, v-erb-b2 erythroblastic leukemia viral oncogene homolog 4, neuro/glioblastoma-derived oncogene homolog (avian); HOXA1, homeobox A1; IGF, insulin growth factor; JAK2, Janus kinase 2; PRL, prolactin; SOCS-3, suppressor of cytokine signaling 3; STAT5, signal transducer and activator of transcription 5; TGF-a, transforming growth factor-alpha.

execute the different actions of STAT5 on cellular differentiation, survival, and proliferation. These gene expression changes may include both direct effects and secondary changes due to STAT5-mediated effects on other transcription factors, including other STAT family members such as STAT3.

\section{The STAT5 signaling node in normal mammary gland development}

STAT5 plays a critical role in the development and differentiation of the normal mammary gland toward lactational competence [7]. It is essential for the generation of luminal progenitor cells that differentiate into alveolar 
cells, although it is not required for the appearance of mammary ductal cells or the production of mammary stem cells $[21,66]$. STAT5A is the more prominent STAT family member expressed in the mammary gland. During pubertal development, its absence results in defects in secondary ductal and side branching [62] and delayed differentiation of terminal end buds when coupled with mammary epithelial cell-targeted ER $\alpha$ overexpression [43]. During pregnancy, it plays an essential role in mammary gland lactational development and in differentiation and expression of milk protein genes [6]. However, in its absence, STAT5B can be upregulated, especially with serial pregnancies, and substitute for STAT5A [9]. STAT5 activation is downregulated at the onset of post-lactational involution [8].

To date, a larger number of signaling pathways and proteins have been identified as contributing to the activation of STAT5 during normal development and lactational differentiation than have been shown to downregulate this pathway (Figure 3). This may be because inadequate levels of STAT5 activation result in the readily apparent defect of insufficient milk production whereas increased STAT5 activation produces the less obvious developmental abnormality of precocious alveolar differentiation during pregnancy and, only later, hyperplasia and cancer $[55,60,66,67]$. Estrogen signaling and progesterone signaling contribute to regulating normal levels of STAT5 expression in the non-pregnant gland $[39,68]$. The transcription factor ELF5 is reported to lie functionally upstream of STAT5 and downstream of prolactin [69]. Its absence compromises STAT5 expression levels and activity in mammary epithelial cells and results in loss of normal lobuloalveolar development [42]. While during normal development STAT5 is activated primarily by PRL signaling pathways, EGF and GH signaling pathways can also contribute [32,70]. ErbB4 has a defined role in mediating STAT5 activation during lactation [35]. Activation of EGF signaling pathways by the introduction of expression of transforming growth factor-alpha (TGF $\alpha$ ) through a mammary epithelial celltargeted transgene can interrupt the downregulation of STAT5 activation and promote mammary epithelial cell survival during involution [70]. PIKE-A, active in AKT signaling, associates with STAT5 and PRLR and its absence results in impaired mammary epithelial cell proliferation and lactation [51]. Pak1 interacts with and serine phosphorylates STAT5 and interruption of the normal function of Pak1 reduces lobuloalveolar growth and milk production [18]. Ablation of $A k t 1$, but not $A k t 2$ or $A k t 3$, interferes with STAT5 activation in late pregnancy and lactation [52,71]. Loss of one copy of the Akt2 gene coupled with ablation of $A k t 1$ results in the loss of STAT5 activation associated with increased expression of caveolin-1 and SOCS-2, negative regulators of STAT5 [52]. The phosphotyrosine phosphatase Shp2 reciprocally modulates STAT5 and STAT3 activation in the mammary epithelium. Deletion of this molecule results in impaired STAT5 activation but slightly increased STAT3 activity [72]. Ablation of Src in normal mammary epithelial cells impairs STAT5 activation through the downregulation of PRLR [27]. Finally, structural molecules outside the mammary epithelial cell, including beta-integrin $[73,74]$ and the basement membrane receptor dystroglycan [75], also play a part in establishing the normal levels of STAT5 activation required for lactational differentiation. Loss of dystroglycan interrupts mammary gland outgrowth and lactation competency that is correlated with decreased STAT5 activity. Negative regulators of STAT5 include TGF- $\beta$, which has been reported to downregulate prolactininduced JAK/STAT5 activation [76,77]. If caveolin-1 is absent, STAT5 activation is increased with subsequent development of mammary hyperplasia and cancer [55].

Candidate downstream mediators of STAT5 activity during normal development include RANKL $[62,63]$ and cyclin D1 [51,62]. STAT5 also has the ability to bind to consensus sequences within the $A k t 1$ locus which define a unique promoter active only in mammary epithelial cells [61].

\section{The STAT5 signaling node in normal mammary stem cells and cancer progenitor cells}

STAT5 has a well-defined role in the regulation of stem and progenitor cells in hematopoietic systems [78-80]. Studies in the mammary gland reveal a role for STAT5 in the development of the mammary epithelial alveolar cell lineage $[21,59,66]$ (Figure 5). The cellular repertoire of the mammary gland is generated by growth and differentiation from a stem cell component coordinated by hormones and cytokines. Mammary stem cells have a distinctive capacity for self-renewal and give rise to the three principal lineages that encompass the normal lobuloalveolar structure of the adult mammary gland: myoepithelial cells that form the basal layer of ducts and alveoli, ductal epithelial cells lining the lumen of ducts, and alveolar epithelial cells that have the capacity to synthesize milk proteins in large quantities [81]. In the absence of STAT5, mammary alveologenesis is abrogated through a reduction in the mammary luminal progenitor cell population $[21,66]$. STAT5 is required not only for proliferation and survival of alveolar cells but also for the generation of alveolar progenitor cells from stem cells. Importantly, the defect is limited to this lineage and loss of STAT5 does not affect the underlying mammary stem cell population. Ductal cells do develop in the absence of STAT5 [21], but while primary ductal extension is normal, impaired side branching is reported [62]. Consistent with the impact of STAT5 loss, gain of a constitutively 


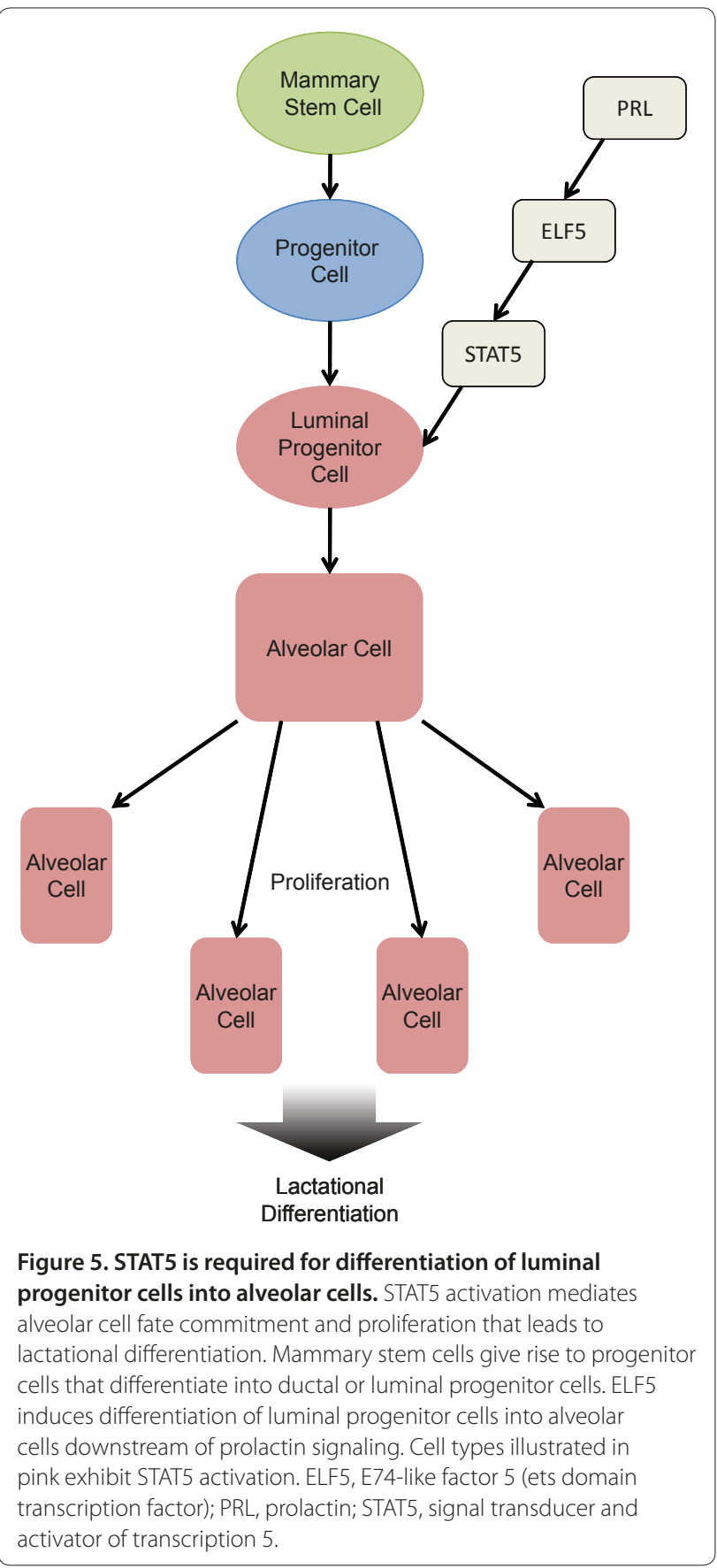

active STAT5A causes otherwise relatively quiescent ductal epithelial cells in virgin mice to undergo rapid expansion and develop into alveolar-like structures [59]. Consistent with the position of ELF5 as a STAT5 regulator, gain of ELF5 induces differentiation of luminal progenitor cells into alveolar cells [69]. In a reciprocal fashion, gain of STAT5 is associated with increased ELF5 expression levels [59], indicating that the two factors have a bidirectional interaction.
Whether or not STAT5 plays a role in cancer progenitor cell pathophysiology is under investigation. Gain-offunction experiments using a Stat5 variant, cS5-F, in which serine 710 is mutated, demonstrate that STAT5 overexpression in mouse models can lead to the development of $\mathrm{ER}^{+} / \mathrm{PR}^{+}$adenocarcinomas harboring a small fraction of $\mathrm{CD}_{4} 4^{+}$cells that are postulated to represent a population of cancer progenitor cells [66].

\section{The STAT5 signaling node in mouse models of breast cancer}

The impact of increasing or decreasing the STAT5 activity on mammary cancer initiation, promotion, and progression has been investigated from a mechanistic perspective by using genetically engineered mouse models (Figure 6). Mammary epithelial cell-targeted overexpression of genetically engineered STAT5 variants is sufficient for initiation, promotion, and progression along a cancer pathway, resulting in mostly well-differentiated adenocarcinomas, sometimes exhibiting a papillary architecture, and a low percentage of undifferentiated carcinomas [60,66,67]. Loss of caveolin-1 in mammary epithelial cells induces hyperactivation of STAT5A signaling, leading to the development of mammary hyperplasias and well-differentiated cancers [55]. STAT5 also contributes to mammary cancer progression initiated by mammary epithelial cell-targeted overexpression of PRL [23], simian virus $40 \mathrm{~T}$ antigen (TAg) [82], and TGF- $\alpha$ [70]. Significantly, JAK2 is required to initiate mammary cancer development by PRL overexpression but is dispensable for cancer cell survival and proliferation [83], exerting a 'hit and run' effect in mammary carcinogenesis. Similarly, loss of STAT5A reduces the prevalence of ER $\alpha$-initiated mammary preneoplasia but does not prevent the development of invasive cancer [43]. Upregulation of growth factors known to contribute to mammary carcinogenesis, including ErbB2 [43,83] and cyclin D1 [43], is found in the cancers that develop in the absence of either JAK2 or STAT5a and that may be responsible for sustaining the cancer cell growth.

\section{The STAT5 signaling node in benign human breast disease and cancer}

Stat5 is expressed in a high proportion of human breast cancers $[84,85]$. Activation of STAT5 in breast cancers is statistically associated with higher levels of differentiation [85] and a better prognosis [84] and response to endocrine therapy when co-expressed with ER $\alpha$ [86]. Consistent with these results, higher expression levels of STAT5 target genes such as IGF-1 and SOCS-2 also correlate with a better prognosis [57]. Decreased expression levels of STAT5A are found more frequently in high-grade breast cancers as compared with normal breast tissue or 


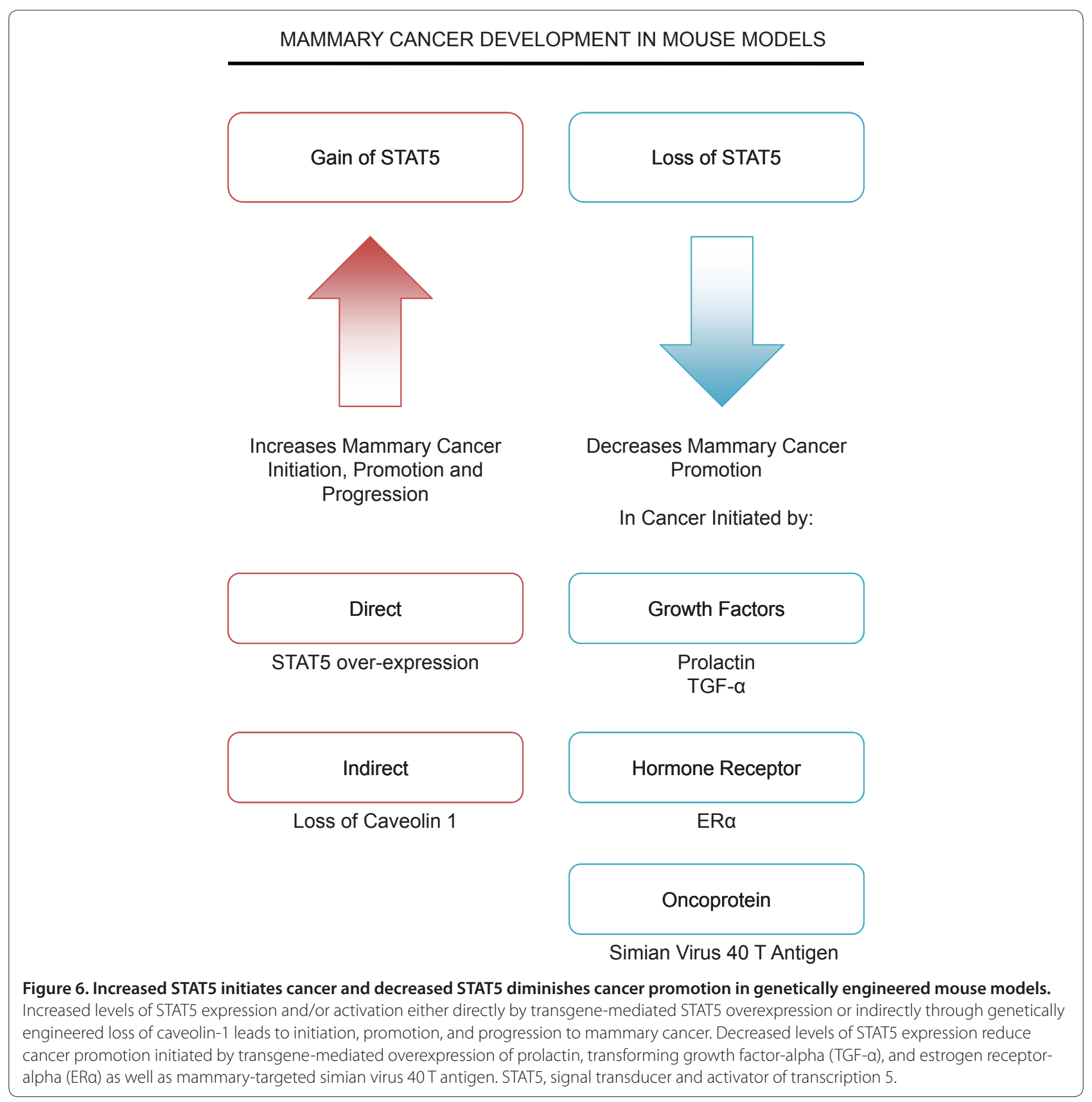

ductal carcinoma in situ lesions. The absence of activated STAT5 correlates with a higher probability of not responding to endocrine therapy [87]. These lower levels of STAT5A are associated with increased expression levels of proto-oncogene B-cell chronic lymphocytic leukemia/lymphoma 6 (BCL6), a transcriptional repressor that recognizes similar DNA target sequences [88]. Interestingly, a PRLR gain-of-function mutant resulting in increased STAT5 signaling is associated with the presence of multiple benign breast fibroadenomas [89].
A correlation between increased STAT5 expression and cellular transformation has also been shown in mammary epithelial cells in which activation levels of STAT5 are increased. Overexpression of the homeobox A1 (HOXA1) gene in these cells induces increased STAT5B expression that is associated with increased cell proliferation, survival, and oncogenic transformation [90]. Interestingly, STAT3, but not STAT5A, is simultaneously induced by HOXA1, and downregulation of either STAT5B or STAT3 is sufficient to abrogate the phenotype. STAT5 
activation mediated by artificial induction of the EPO receptor into the benign non-invasive rat mammary cell line, Rama 37, leads to increased colony formation, invasion, migration, and changes in adhesion associated with increased extracellular signal-regulated kinase (ERK) and AKT [91].

The observations in human breast cells coupled with the pathophysiological studies in mouse models raise interesting questions about the role of STAT5 in human breast cancer. It would appear that, when the mechanistic mouse studies are taken together with the descriptive human studies, STAT5 activation is definitively compatible with cancer cell growth and increased levels of STAT5 activation may contribute to cancer progression. However, the cancers exhibiting STAT5 expression are more differentiated and statistically more likely to respond to endocrine therapy and perhaps are therefore associated with a better prognosis. Experiments in human breast cancer cell lines have demonstrated that this may be because STAT5 is able to maintain some of its ability to promote cellular differentiation in cancer cells, as it does during normal development. These studies have identified specific cellular behaviors and downstream genes that can be influenced by changes in STAT5 expression and activation (Figure 7).

In some experimental systems, STAT5 has been shown to contribute to differentiation of breast cancer cells and this contribution is reminiscent of its role in normal mammary gland development. In BT-20 and T47D breast cancer cells, the combination of STAT5 and Jak2 overexpression induces a mesenchymal-to-epithelial transition when the cells are grown in a three-dimensional matrigel assay. The cells shift to a luminal epithelial cell phenotype and become less invasive [92]. Paralleling these results, differentiation as measured in a threedimensional culture assay is impaired when kinase-dead ErbB4 mutants that reduce STAT5 activation levels are placed into MDA-MB-468 breast cancer cells [33]. STAT5 has been found to attenuate prolactin signaling to activating protein-1 (AP-1), perhaps through direct binding. Loss of STAT5 in T47D cells increases prolactininduced AP-1 signaling, matrix metalloproteinase-2, and invasive behavior [93], and forced increased expression levels of STAT5 can inhibit motility of MCF-7 and T47D cells [13].

In other experiments, STAT5 activation in cancer cells enhances behaviors conventionally associated with advanced malignancy. The same experiments that demonstrated that forced expression of STAT5 in MCF-7 and T47D cells suppresses cell motility showed that it enhanced cell survival and anchorage-independent growth [13]. In MDA-MB-231 and BT-549 cells, knockdown of STAT5B can inhibit beta-1-integrin-mediated cell migration [14].
BCL6 represents a gene whose upregulation is associated with loss of differentiation of breast cancer cells when STAT5 expression is reduced [88]. STAT5A, but not STAT5B, is able to repress BCL6 expression through a prolactin-induced mechanism. Whereas STAT5 represses BCL6 expression, STAT3 increases BCL6 expression. However, STAT5 is dominant over its related family member STAT3 in regulating BCL6 expression levels in T-47D and SK-BR-3 cells [65]. Moreover, in MDA-MB-468 cells, the same authors demonstrated that simultaneous STAT5 and STAT3 activation resulted in decreased proliferation and increased sensitivity to paclitaxel and vinorelbine as compared with cells with STAT3 activation alone.

STAT5A signaling in breast cancer cells can be modified by interactions with c-Myb [53] and Brk [54]. cMyb and STAT5A associate in a PRL-inducible manner in T47D and MCF7 breast cancer cells, stimulate expression of STAT5A downstream genes, and are associated with increased PRL-induced cell proliferation. Brk can phosphorylate STAT5 through a mechanism involving signal-transducing adaptor protein 2 (STAP-2). Knockdowns of STAT5B, Brk, and STAP-2 equivalently reduce proliferation of T47D breast cancer cells.

Downstream STAT5 genes, including SOCS-3, can feedback to regulate STAT5 activity in breast cancer cell lines. For example, overexpression of SOCS-3 in T47D cells reduces PRL-induced STAT5 phosphorylation and this is correlated with decreased cell proliferation [94]. Expression of PTPN9 (protein tyrosine phosphatase, non-receptor type 9) is reported to reduce STAT5 activation coincident with growth inhibition as measured in soft agar assays by using SKBR3 and MDA-MB-231 breast cancer cell lines, perhaps (in whole or in part) through regulation of ErbB2 and EGFR phosphorylation [95].

STAT5 regulates expression of genes that promote cell survival and proliferation in breast cancer cells. For example, STAT5 can induce expression of heat shock protein 90-A (HSP90A), a protein that can promote cancer cell survival. In SKBR3 breast cancer cells, PRL increases HSP90A, and STAT5B activates the HSP90A promoter [96]. IGF was found to lie downstream of STAT5 in breast cancers, including ER $\alpha$-negative breast cancer cells [12,57]. Cyclin D1 also lies downstream of STAT5 in breast cancers $[12,15,16,38]$. It should be understood that, while HSP90A, IGF, and cyclin D1 lie downstream of STAT5 activation, their expression patterns, activity, and impact on cellular growth can be modified by other cellular factors and signaling molecules expressed in breast cancer cells [36,97-99].

STAT5 activation has been correlated with response to endocrine therapy, although currently there is a disconnection between available in vivo and in vitro data. 


\section{HUMAN BREAST CANCER}

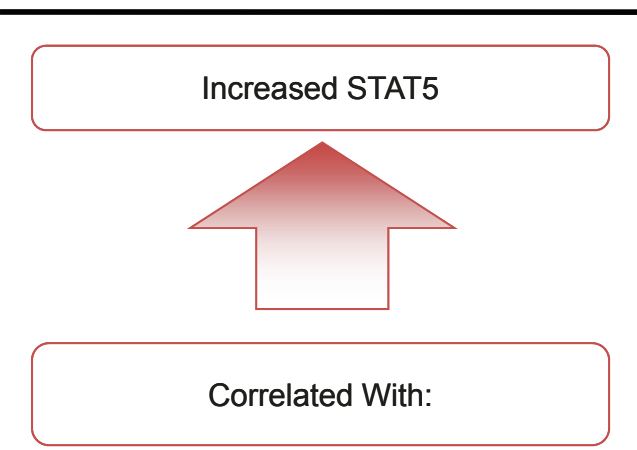

Increased Differentiation

Better Response to Endocrine Therapy

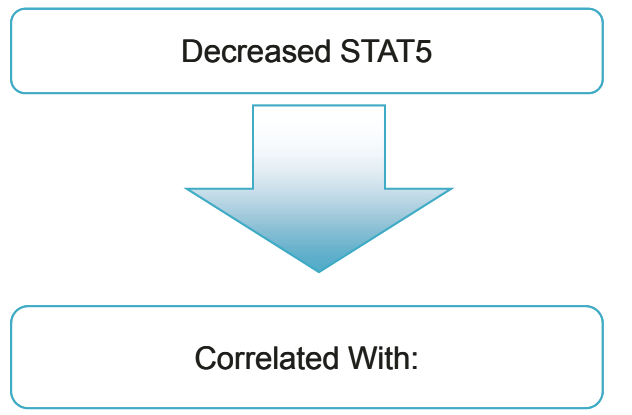

Poor Clinical Outcome

Worse Response to Endocrine Therapy

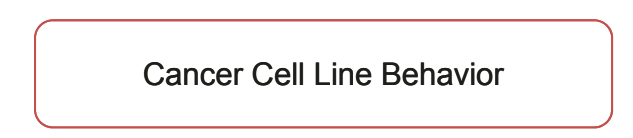

BT-20 Mesenchymal to epithelial transition T47D Mesenchymal to epithelial transition MCF-7 inhibits motility

T47D inhibits mobility SKBR3 enhanced survival MCF-7 enhanced survival T47D enhanced survival T47D increased tamoxifen resistance SKBR3 decreased response to trastuzumab MDA-MB-468 increased sensitivity to paclitaxel and vinorelbine

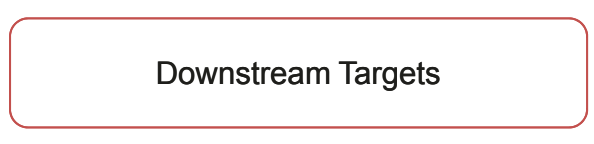

Reduced BCL6

Reduced AP-1 signaling Increased HSP90A Increased IGF Increased Cyclin D1

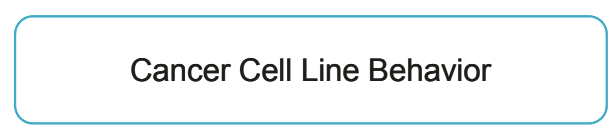

MDA-MB-468 impaired differentiation

SKBR3 growth inhibition MDA-MB-231 growth inhibition T47D increased invasiveness MDA-MB-231 inhibits migration BT-549 inhibits migration

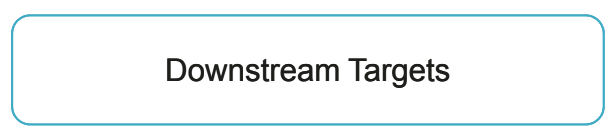

Increased BCL6 Increased AP-1 signaling

Figure 7. STAT5 expression in human breast cancer is generally associated with increased differentiation. In human breast cancer tissue, STAT5 expression has been reproducibly associated with increased differentiation and a better prognosis and response to endocrine therapy. Experiments that alter STAT5 expression levels in breast cancer cell lines revealed a link between the presence of STAT5 and increased differentiation in BT-20, T47D, and MDA-MB-468 breast cancer cell lines. Increased cell motility, invasiveness, and migration are behaviors that can be found in association with decreased differentiation. In MCF-7 andT47D cells lines, STAT5 inhibits motility, and in the T47D cell line loss of STAT5 increases invasiveness and this is consistent with the correlation between STAT5 and increased differentiation. However, in MDA-MB-231 and BT-549, loss of STAT5 actually inhibits migration. Increased sensitivity to therapy is considered a good prognostic sign, and in the MDA-MB-468 cell line, STAT5 is correlated with increased sensitivity to paclitaxel and vinorelbine. However, in SKBR3, MCF-7, and T47D cell lines, experiments have correlated the presence of STAT5 with increased cell survival and, in T47D cells, resistance to tamoxifen and, in SKBR3 cells, a decreased response to trastuzumab. In SKBR3 and MD-MBA-231 cells, loss of STAT5 is actually correlated with growth inhibition. These sometimes consistent and sometimes conflicting results in different breast cancer cell lines indicate that the relative impact of STAT5 on cell differentiation, survival, and proliferation can be cell linespecific. BCL6 gene expression and activating protein-1 (AP-1) signaling are reduced by increased STAT5 signaling and increased by reduced STAT5 signaling. Identified downstream STAT5 genes in breast cancer cells include heat shock protein 90-A (HSP90A), insulin growth factor (IGF), and cyclin D1. BCL6, proto-oncogene B-cell chronic lymphocytic leukemia/lymphoma 6; STAT5, signal transducer and activator of transcription 5.

Descriptive studies using human breast cancer tissue demonstrate a positive correlation between STAT5 activation and response to endocrine therapy [86,87], whereas constitutive activation of STAT5B in T47D 
breast cancer cells is reported to induce tamoxifen resistance [16].

\section{Development of a unifying hypothesis of STAT5 action and future directions}

An examination of the different results from both normal and malignant mammary epithelial cells, in mice and in women, reveals some commonalities in the different experimental systems employed. One is the mechanistic impact of STAT5 activation on differentiation in the mouse and cell line studies coupled with its correlation with differentiation in the human breast cancer tissue studies. In both normal and malignant mammary epithelial cells, STAT5 is positively associated with differentiation. Similarly, STAT5 contributes to improving cell survival and increasing cell proliferation in both normal and malignant cells. However, cellular differentiation appears to be the most frequently altered feature found when STAT5 activation or expression levels are high and therefore one significant factor in a unifying hypothesis of STAT5 action.

A second feature of a unifying hypothesis of STAT5 action is that, although many of the signaling pathways that activate STAT5 and cellular proteins that interact with it are similar in normal and malignant mammary epithelial cells, differences in the degree to which the different components contribute exist. In normal mammary epithelial cells, the PRL/PRLR/JAK2 pathway dominates, whereas in cancer cells significant STAT5 activation can occur through EGF and c-Src with contributions from estrogen and progesterone signaling pathways and even the EPO pathway. Another difference between normal and malignant mammary epithelial cells lies in the relative contributions of STAT5A and STAT5B. In normal mammary epithelial cells, STAT5A is the dominant actor, whereas in malignant mammary epithelial cells, STAT5B can be the more significant contributor.

A third feature for a unifying hypothesis for STAT5 action is its ability to contribute to cancer initiation, promotion, and progression and at the same time be a critical component of normal mammary gland development. In this respect, it shares the challenges of other growth factor pathways involved in normal mammary gland development, including estrogen, progesterone, EGF, and IGF pathways. When properly regulated, these pathways mediate normal growth, cellular proliferation, and differentiation but can contribute to neoplastic transition and unrestrained cellular proliferation when their activation becomes unbalanced or associated with oncogenic changes in the cell or both.

Finally, the contribution of STAT5 to the specification of progenitor cells has to be considered in any unifying hypothesis of STAT5 action. Here, there is clear definition of its role in specifying alveolar cell lineage differentiation during normal development, but its contribution to cancer progenitor cell biology is less well defined. One can speculate that it may 'specify' a type of breast cancer progenitor cell, perhaps a more differentiated one that shares morphological or biological features with alveolar cells. In support of this conjecture, STAT5 overexpression in mice is associated with the development of papillary adenocarcinomas, a more differentiated histological type that is not commonly found in genetically engineered mouse models of cancer.

At present, a unifying hypothesis of STAT5 action in mammary epithelial cells would include the following statements. STAT5 is a protein with dominant effects on cellular differentiation and lineage specification that lead to proliferation and survival of specific mammary cell types. It has the ability to contribute to growth and survival in both normal and cancer cells. Well-established mammary cellular growth factors and hormones from outside the cell acting through their receptors are the most frequent activators of STAT5. The degree to which the different pathways contribute to STAT5 activation varies between normal and malignant mammary cells and between different types of breast cancer cells.

Future directions for study build upon this broad hypothesis. While the role of STAT5 in lineage specification of normal mammary epithelial cells appears clear, it is important to know whether STAT5 also can specify specific lineages of breast cancers. Human breast cancer is not a unitary disease but rather is composed of different types with some unique pathological and molecular features. One hope is that we can build upon our previous success with targeted endocrine and ErbB2targeted therapy to develop a more effective treatment that is more specifically designed for specific breast cancer types. If STAT5 were to specify a particular type of breast cancer, this knowledge could be used for better treatment and prevention. Related to this is the possibility that the activity level of STAT 5 could be used as a marker to help select individuals who might respond better to particular therapies or indicate women who might require closer follow-up or a different approach because their risk of non-response would be increased. The most immediate need for additional research in this area might be in regard to endocrine therapy and to the combination of trastuzumab with EPO-type drugs. In regard to endocrine therapy, we need to know why activation of STAT5 is correlated with a higher response rate. Is this a simple correlation with ER $\alpha$ status and higher differentiation levels, or does STAT5 activation play a mechanistic role in improving the response? The fact that an interaction between EPO and trastuzumab has been identified raises the possibility that other competing interactions between signaling pathways may occur and should be sought. 
STAT5 is actually two proteins, STAT5A and STAT5B, embedded within a network of cellular signaling pathways. Future studies will have to try a more global analysis of this network as opposed to focusing on a limited number of readouts. This is true for all three major types of experiments that examine STAT5 action: mouse model studies, tissue culture cell studies, and human tissue studies. In each of these approaches, investigators will need to examine not only STAT5 activation but also associated family members and the constellation of interacting proteins and signaling pathways that impact STAT5. Finally, STAT5 is described as a transcription factor. Whereas some of its downstream genes are characterized, the transcriptional networks that lead to the different cellular behaviors associated with STAT5 activation are not fully defined. Further definition of the genetic networks lying downstream of STAT5 remains a highly relevant research goal.

This article is part of a review series on Key signalling nodes in mammary gland development and cancer, edited by Adrian Lee and Charles Streuli. Other articles in the series can be found online at http://breast-cancer-research.com/series/signalling_nodes.

\section{Abbreviations}

AKT, serine/threonine protein kinase Akt; AP-1, activating protein-1; BCL6, proto-oncogene B-cell chronic lymphocytic leukemia/lymphoma 6; Brk, breast tumor kinase; c-Myb, v-Myb myeloblastosis viral oncogene homolog (avian); c-Src, human cellular-Src; EGF, epidermal growth factor; EGFR, epidermal growth factor receptor; ELF5, E74-like factor 5 (ets domain transcription factor); EPO, erythropoietin; ER, estrogen receptor; ErbB4, v-erb-b2 erythroblastic leukemia viral oncogene homolog 4, neuro/glioblastoma-derived oncogene homolog (avian); GH, growth hormone; HOXA1, homeobox A1; HSP90A, heat shock protein 90-A; IGF, insulin growth factor; JAK, Janus kinase; Pak1, p21activated kinase 1; PIKE-A, PI 3-kinase enhancer A; PR, progesterone receptor; PRL, prolactin; PRLR, prolactin receptor; RANKL, receptor activator of nuclear factor-kappa-B ligand; rHuEPO, recombinant human erythropoietin; SOCS, suppressor of cytokine signaling; STAP-2, signal-transducing adaptor protein 2; STAT, signal transducer and activator of transcription; TGF, transforming growth factor.

\section{Competing interests}

The authors declare that they have no competing interests.

\section{Authors' information}

REN, SM, ESD-C, and MCC contributed equally and are listed in reverse alphabetical order.

\section{Acknowledgments}

This project was supported by the following grants: NIH NCI RO1 CA112176 (PAF), NIH NCI P30CA051008 (PAF), R31-10069 (WCU program) through the National Research Foundation of Korea funded by the Ministry of Education, Science and Technology (PAF), NIH NCI 2RO1 CA88041-1OS1 (MCC), Department of Defense Breast Cancer Program Predoctoral Traineeship Award BC100440 (REN), and KG080359 (ESD-C) from The Susan B. Komen Breast Cancer Foundation (now known as Susan G. Komen for the Cure). The content is solely the responsibility of the authors and does not necessarily represent the official views of the National Cancer Institute or the National Institutes of Health. Furthermore, the funding bodies had no role in study design, collection, analysis and interpretation of data, writing of the manuscript, or the decision to submit the manuscript.

\section{Author details}

'Department of Oncology, Lombardi Comprehensive Cancer Center, Georgetown University, 3970 Reservoir Road NW, Research Building, Room 520A, Washington, DC 20057, USA. ²Department of Medicine, Georgetown University, 3970 Reservoir Road NW, Research Building, Room 520A, Washington, DC 20057, USA. ${ }^{3}$ World Class University Research Center of Nanobiomedical Science, Dankook University, San 29, Anseo-Dong, Cheonan, 330-714, Korea.

Published: 14 October 2011

References

1. Hennighausen L, Robinson GW: Interpretation of cytokine signaling through the transcription factors STAT5A and STAT5B. Genes Dev 2008, 22:711-721.

2. Desrivières S, Kunz C, Barash I, Vafaizadeh V, Borghouts C, Groner B: The Biological Functions of the Versatile Transcription Factors STAT3 and STAT5 and New Strategies for their Targeted Inhibition. J Mammary Gland Biol Neoplasia 2006, 11:75-87.

3. Ferbeyre G, Moriggl R: The role of Stat5 transcription factors as tumor suppressors or oncogenes. Biochim Biophys Acta 2011, 1815:104-114.

4. Silva CM: Role of STATs as downstream signal transducers in Src family kinase-mediated tumorigenesis. Oncogene 2004, 23:8017-8023.

5. Liu X, Robinson GW, GouilleuX F, Groner B, Hennighausen L: Cloning and expression of Stat 5 and an additional homologue (Stat5b) involved in prolactin signal transduction in mouse mammary tissue. Proc Natl Acad Sci USA 1995, 92:8831-8835.

6. Liu X, Robinson GW, Wagner KU, Garrett L, Wynshaw-Boris A, Hennighausen L: Stat5a is mandatory for adult mammary gland development and lactogenesis. Genes Dev 1997, 11:179-186.

7. Hennighausen L, Robinson GW, Wagner KU, Liu X: Developing a mammary gland is a stat affair. J Mammary Gland Bio/ Neoplasia 1997, 2:365-372.

8. Li M, Liu X, Robinson G, Bar-Peled U, Wagner KU, Young WS, Hennighausen L, Furth PA: Mammary-derived signals activate programmed cell death during the first stage of mammary gland involution. Proc Natl Acad Sci USA 1997, 94:3425-3430.

9. Liu X, Gallego MI, Smith GH, Robinson GW, Hennighausen L: Functional rescue of Stat5a-null mammary tissue through the activation of compensating signals including Stat5b. Cell Growth Differ 1998, 9:795-803.

10. Udy GB, Towers RP, Snell RG, Wilkins RJ, Park SH, Ram PA, Waxman DJ, Davey $H W$ : Requirement of STAT5 $\mathrm{b}$ for sexual dimorphism of body growth rates and liver gene expression. Proc Natl Acad Sci U S A 1997, 94:7239-7244.

11. Pontillo C, García M, Peña D, Cocca C, Chiappini F, Alvarez L, Kleiman de Pisarev D, Randi A: Activation of c-Src/ HER1/ STAT5b and HER1/ ERK1/2 signaling pathways and cell migration by hexachlorobenzene in MDAMB-231 human breast cancer cell line. Toxicol Sci 2011, 120:284-296.

12. Lim E-J, Joung Y-H, Jung S-M, Park SH, Park JH, Kim SY, Hwang TS, Hong DY, Chung SC, Ye S-K, Moon E-S, Park EU, Park T, Chung I-M, Yang YM: Hemin inhibits cyclin D1 and IGF-1 expression via STAT5b under hypoxia in ERalpha-negative MDA-MB 231 breast cancer cells. Int J Oncol 2010, 36:1243-1251.

13. Tang J-Z, Zuo Z-H, Kong X-J, Steiner M, Yin Z, Perry JK, Zhu T, Liu D-X, Lobie PE: Signal transducer and activator of transcription (STAT)-5A and STAT5B differentially regulate human mammary carcinoma cell behavior. Endocrinology 2010, 151:43-55.

14. Bernaciak TM, Zareno J, Parsons JT, Silva CM: A novel role for signal transducer and activator of transcription $5 b$ (STAT5b) in beta 1-integrinmediated human breast cancer cell migration. Breast Cancer Res 2009, 11:R52.

15. Joung Y-H, Lim E-J, Kim M-S, Lim SD, Yoon S-Y, Lim YC, Yoo YB, Ye S-K, ParkT, Chung I-M, Bae K-Y, Yang YM: Enhancement of hypoxia-induced apoptosis of human breast cancer cells via STAT5b by momilactone B. Int J Oncol 2008, 33:477-484

16. Fox EM, BernaciakTM, Wen J, Weaver AM, Shupnik MA, Silva CM: Signal transducer and activator of transcription $5 \mathrm{~b}, \mathrm{c}$-Src, and epidermal growth factor receptor signaling play integral roles in estrogen-stimulated proliferation of estrogen receptor-positive breast cancer cells. $\mathrm{Mol}$ Endocrinol 2008, 22:1781-1796.

17. Tan $\mathrm{SH}$, Nevalainen MT: Signal transducer and activator of transcription 5A/B in prostate and breast cancers. Endocr Relat Cancer 2008, 15:367-390.

18. Wang R-A, Vadlamudi RK, Bagheri-Yarmand R, Beuvink I, Hynes NE, Kumar R: Essential functions of p21-activated kinase 1 in morphogenesis and differentiation of mammary glands. J Cell Biol 2003, 161:583-592. 
19. Johnson KJ, Peck AR, Liu C, Tran TH, Utama FE, Sjolund AB, Schaber JD, Witkiewicz AK, Rui H: PTP1B suppresses prolactin activation of Stat5 in breast cancer cells. Am J Pathol 2010, 177:2971-2983.

20. Wagner KU, Rui H: Jak2/Stat5 signaling in mammogenesis, breast cancer initiation and progression. J Mammary Gland Biol Neoplasia 2008, 13:93-103.

21. Yamaji D, Na R, Feuermann Y, Pechhold S, Chen W, Robinson GW, Hennighausen L: Development of mammary luminal progenitor cells is controlled by the transcription factor STAT5A. Genes Dev 2009, 23:2382-2387.

22. Bernichtein S, Touraine P, Goffin V: New concepts in prolactin biology. J Endocrinol 2010, 206:1-11.

23. Arendt LM, Evans LC, Rugowski DE, Garcia-Barchino MJ, Rui H, Schuler LA: Ovarian hormones are not required for PRL-induced mammary tumorigenesis, but estrogen enhances neoplastic processes. J Endocrinol 2009, 203:99-110.

24. Arendt LM, Rugowski DE, Grafwallner-Huseth TA, Garcia-Barchino MJ, Rui H, Schuler LA: Prolactin-induced mouse mammary carcinomas model estrogen resistant luminal breast cancer. Breast Cancer Res 2011, 13:R11.

25. Kelly PA, Bachelot A, Kedzia C, Hennighausen L, Ormandy CJ, Kopchick JJ, Binart $\mathrm{N}$ : The role of prolactin and growth hormone in mammary gland development. Mol Cell Endocrinol 2002, 197:127-131.

26. Neilson LM, Zhu J, Xie J, Malabarba MG, Sakamoto K, Wagner K-U, Kirken RA Rui $\mathrm{H}$ : Coactivation of janus tyrosine kinase (Jak) 1 positively modulates prolactin-Jak2 signaling in breast cancer: recruitment of ERK and signal transducer and activator of transcription (Stat)3 and enhancement of Akt and Stat5a/b pathways. Mol Endocrinol 2007, 21:2218-2232.

27. Watkin H, Richert MM, Lewis A, Terrell K, McManaman JP, Anderson SM: Lactation failure in Src knockout mice is due to impaired secretory activation. BMC Dev Biol 2008, 8:6.

28. Fox EM, Andrade J, Shupnik MA: Novel actions of estrogen to promote proliferation: integration of cytoplasmic and nuclear pathways. Steroids 2009, 74:622-627

29. García-Martínez JM, Calcabrini A, González L, Martín-Forero E, Agulló-Ortuño MT, Simon V, Watkin H, Anderson SM, Roche S, Martín-Pérez J: A non-catalytic function of the Src family tyrosine kinases controls prolactin-induced Jak2 signaling. Cell Signal 2010, 22:415-426.

30. Liang K, Esteva FJ, Albarracin C, Stemke-Hale K, Lu Y, Bianchini G, Yang C-Y, Li Y, Li X, Chen C-T, Mills GB, Hortobagyi GN, Mendelsohn J, Hung M-C, Fan Z Recombinant human erythropoietin antagonizes trastuzumab treatment of breast cancer cells via Jak2-mediated Src activation and PTEN inactivation. Cancer Cell 2010, 18:423-435.

31. Groner B, Hynes NE: Unfavorable drug interactions in targeted breast cancer therapy. Cancer Cell 2010, 18:401-402.

32. Gallego MI, Binart N, Robinson GW, Okagaki R, Coschigano KT, Perry J, Kopchick JJ, Oka T, Kelly PA, Hennighausen L: Prolactin, growth hormone, and epidermal growth factor activate Stat5 in different compartments of mammary tissue and exert different and overlapping developmental effects. Dev Biol 2001, 229:163-175.

33. Tvorogov D, Sundvall M, Kurppa K, Hollmén M, Repo S, Johnson MS, Elenius K: Somatic mutations of ErbB4: selective loss-of-function phenotype affecting signal transduction pathways in cancer. J Biol Chem 2009, 284:5582-5591.

34. Yang S, Raymond-Stintz MA, Ying W, Zhang J, Lidke DS, Steinberg SL, Williams L, Oliver JM, Wilson BS: Mapping ErbB receptors on breast cancer cell membranes during signal transduction. J Cell Sci 2007, 120:2763-2773.

35. Jones FE, Welte T, Fu XY, Stern DF: ErbB4 signaling in the mammary gland is required for lobuloalveolar development and Stat5 activation during lactation. J Cell Biol 1999, 147:77-88.

36. Himpe E, Kooijman R: Insulin-like growth factor-I receptor signal transduction and the Janus Kinase/Signal Transducer and Activator of Transcription (JAK-STAT) pathway. Biofactors 2009, 35:76-81.

37. Wood CE, Register TC, Cline JM: Transcriptional profiles of progestogen effects in the postmenopausal breast. Breast Cancer Res Treat 2009, 114:233-242.

38. Lange CA, Richer JK, Shen T, Horwitz KB: Convergence of progesterone and epidermal growth factor signaling in breast cancer. Potentiation of mitogen-activated protein kinase pathways. J Biol Chem 1998, 273:31308-31316.

39. Santos SJ, Haslam SZ, Conrad SE: Estrogen and progesterone are critical regulators of Stat5a expression in the mouse mammary gland. Endocrinology 2008, 149:329-338.
40. Petersen $H$, Haldosén LA: EGF modulates expression of STAT5 in mammary epithelial cells. Exp Cell Res 1998, 243:347-358.

41. Menzies KK, Lee HJ, Lefèvre C, Ormandy CJ, Macmillan KL, Nicholas KR: Insulin, a key regulator of hormone responsive milk protein synthesis during lactogenesis in murine mammary explants. Funct Integr Genomics 2010, 10:87-95.

42. Choi YS, Chakrabarti R, Escamilla-Hernandez R, Sinha S: Elf5 conditional knockout mice reveal its role as a master regulator in mammary alveolar development: failure of Stat 5 activation and functional differentiation in the absence of Elf5. Dev Biol 2009, 329:227-241.

43. Miermont AM, Parrish AR, Furth PA: Role of ERalpha in the differential response of Stat5a loss in susceptibility to mammary preneoplasia and DMBA-induced carcinogenesis. Carcinogenesis 2010, 31:1124-1131.

44. Boerner JL, Gibson MA, Fox EM, Posner ED, Parsons SJ, Silva CM, Shupnik MA: Estrogen negatively regulates epidermal growth factor (EGF)-mediated signal transducer and activator of transcription 5 signaling in human EGF family receptor-overexpressing breast cancer cells. Mol Endocrinol 2005, 19:2660-2670

45. Björnström L, Kilic E, Norman M, Parker MG, Sjöberg M: Cross-talk between Stat $5 \mathrm{~b}$ and estrogen receptor-alpha and -beta in mammary epithelial cells. J Mol Endocrinol 2001, 27:93-106.

46. Buser AC, Gass-Handel EK, Wyszomierski SL, Doppler W, Leonhardt SA, Schaack J, Rosen JM, Watkin H, Anderson SM, Edwards DP: Progesterone receptor repression of prolactin/signal transducer and activator of transcription 5-mediated transcription of the beta-casein gene in mammary epithelial cells. Mol Endocrinol 2007, 21:106-125.

47. Bertucci PY, Quaglino A, Pozzi AG, Kordon EC, Pecci A: Glucocorticoidinduced impairment of mammary gland involution is associated with STAT5 and STAT3 signaling modulation. Endocrinology 2010, 151:5730-5740.

48. Rocha-Viegas L, Vicent GP, Barañao JL, Beato M, Pecci A: Glucocorticoids repress bcl-X expression in lymphoid cells by recruiting STAT5B to the P4 promoter. J Biol Chem 2006, 281:33959-33970.

49. Litterst CM, Kliem S, Marilley D, Pfitzner E: NCoA-1/SRC-1 is an essential coactivator of STAT5 that binds to the FDL motif in the alpha-helical region of the STAT5 transactivation domain. J Bio/ Chem 2003, 278:45340-45351.

50. Cella N, Groner B, Hynes NE: Characterization of Stat5a and Stat5b homodimers and heterodimers and their association with the glucocortiocoid receptor in mammary cells. Mol Cell Biol 1998, 18:1783-1792.

51. Chan C-B, Liu X, Ensslin MA, Dillehay DL, Ormandy CJ, Sohn P, Serra R, Ye K. PIKE-A is required for prolactin-mediated STAT5a activation in mammary gland development. EMBO J 2010, 29:956-968.

52. Chen CC, Boxer RB, Stairs DB, Portocarrero CP, Horton RH, Alvarez JV, Birnbaum MJ, Chodosh LA: Akt is required for Stat5 activation and mammary differentiation. Breast Cancer Res 2010, 12:R72.

53. Fang F, Rycyzyn MA, Clevenger CV: Role of c-Myb during prolactin-induced signal transducer and activator of transcription 5 a signaling in breast cancer cells. Endocrinology 2009, 150:1597-1606.

54. Ikeda O, Mizushima A, Sekine Y, Yamamoto C, Muromoto R, Nanbo A, Oritan K, Yoshimura A, Matsuda T: Involvement of STAP-2 in Brk-mediated phosphorylation and activation of STAT5 in breast cancer cells. Cancer Sci 2011, 102:756-761

55. Sotgia F, Williams TM, Schubert W, Medina F, Minetti C, Pestell RG, Lisanti MP. Caveolin-1 deficiency (-/-) conveys premalignant alterations in mammary epithelia, with abnormal lumen formation, growth factor independence, and cell invasiveness. Am J Pathol 2006, 168:292-309.

56. Davey HW, Xie T, McLachlan MJ, Wilkins RJ, Waxman DJ, Grattan DR: STAT5b is required for GH-induced liver IGF-I gene expression. Endocrinology 2001, 142:3836-3841

57. Haffner MC, Petridou B, Peyrat JP, Révillion F, Müller-Holzner E, Daxenbichler G, Marth C, Doppler W: Favorable prognostic value of SOCS2 and IGF-I in breast cancer. BMC Cancer 2007, 7:136.

58. Wang $\mathrm{Y}$, Jiang $\mathrm{H}$ : Identification of a distal STAT5-binding DNA region that may mediate growth hormone regulation of insulin-like growth factor-I gene expression. J Biol Chem 2005, 280:10955-10963.

59. Dong J, Tong T, Reynado AM, Rosen JM, Huang S, Li Y: Genetic manipulation of individual somatic mammary cells in vivo reveals a master role of STAT5a in inducing alveolar fate commitment and lactogenesis in the absence of reproductive hormones. Dev Biol 2010, 346:196-203.

60. lavnilovitch E, Cardiff RD, Groner B, Barash I: Deregulation of Stat5 expression and activation causes mammary tumors in transgenic mice. Int 
J Cancer 2004, 112:607-619

61. Creamer BA, Sakamoto K, Schmidt JW, Triplett AA, Moriggl R, Wagner K-U: Stat5 promotes survival of mammary epithelial cells through transcriptional activation of a distinct promoter in Akt1. Mol Cell Biol 2010, 30:2957-2970

62. Santos SJ, Haslam SZ, Conrad SE: Signal transducer and activator of transcription 5a mediates mammary ductal branching and proliferation in the nulliparous mouse. Endocrinology 2010, 151:2876-2885.

63. Srivastava S, Matsuda M, Hou Z, Bailey JP, Kitazawa R, Herbst MP, Horseman ND: Receptor activator of NF-kappaB ligand induction via Jak2 and Stat5a in mammary epithelial cells. J Bio/ Chem 2003, 278:46171-46178.

64. Hosui A, Kimura A, Yamaji D, Zhu B-mei, Na R, Hennighausen L: Loss of STAT5 causes liver fibrosis and cancer development through increased TGF\{beta\} and STAT3 activation. J Exp Med 2009, 206:819-831.

65. Walker SR, Nelson EA, Zou L, Chaudhury M, Signoretti S, Richardson A, Frank DA: Reciprocal effects of STAT5 and STAT3 in breast cancer. Mol Cancer Res 2009, 7:966-976

66. Vafaizadeh V, Klemmt P, Brendel C, Weber K, Doebele C, Britt K, Grez M, Fehse $B$, Desrivières S, Groner B: Mammary epithelial reconstitution with genemodified stem cells assigns roles to Stat5 in luminal alveolar cell fate decisions, differentiation, involution, and mammary tumor formation. Stem Cells 2010, 28:928-938.

67. Eilon T, Barash I: Different gene-expression profiles for the poorly differentiated carcinoma and the highly differentiated papillary adenocarcinoma in mammary glands support distinct metabolic pathways. BMC Cancer 2008, 8:270.

68. Nevalainen MT, Xie J, Bubendorf $L$, Wagner K-U, Rui H: Basal activation of transcription factor signal transducer and activator of transcription (Stat5) in nonpregnant mouse and human breast epithelium. Mol Endocrinol 2002, 16:1108-1124

69. Oakes SR, Naylor MJ, Asselin-Labat M-L, Blazek KD, Gardiner-Garden M, Hilton HN, Kazlauskas M, Pritchard MA, Chodosh LA, Pfeffer PL, Lindeman GJ, Visvader JE, Ormandy CJ: The Ets transcription factor Elf5 specifies mammary alveolar cell fate. Genes Dev 2008, 22:581-586.

70. Humphreys RC, Hennighausen L: Transforming growth factor alpha and mouse models of human breast cancer. Oncogene 2000, 19:1085-1091.

71. Maroulakou IG, Oemler W, Naber SP, Klebba I, Kuperwasser C, Tsichlis PN: Distinct roles of the three Akt isoforms in lactogenic differentiation and involution. J Cell Physio/ 2008, 217:468-477

72. Ke Y, Lesperance J, Zhang EE, Bard-Chapeau EA, Oshima RG, Muller WJ, Feng G-S: Conditional deletion of Shp2 in the mammary gland leads to impaired lobulo-alveolar outgrowth and attenuated Stat5 activation. J Biol Chem 2006, 281:34374-34380

73. Edwards GM, Wilford FH, Liu X, Hennighausen L, Djiane J, Streuli CH: Regulation of mammary differentiation by extracellular matrix involves protein-tyrosine phosphatases. J Bio/ Chem 1998, 273:9495-9500.

74. Naylor MJ, Li N, Cheung J, Lowe ET, Lambert E, Marlow R, Wang P, Schatzmann F, Wintermantel T, Schüetz G, Clarke AR, Mueller U, Hynes NE, Streuli $\mathrm{CH}$ : Ablation of beta 1 integrin in mammary epithelium reveals a key role for integrin in glandular morphogenesis and differentiation. J Cell Biol 2005, 171:717-728.

75. Leonoudakis D, Singh M, Mohajer R, Mohajer P, Fata JE, Campbell KP, Muschler $J$ : Dystroglycan controls signaling of multiple hormones through modulation of STAT5 activity. J Cell Sci 2010, 123:3683-3692.

76. Wu W-J, Lee C-F, Hsin C-H, Du J-Y, Hsu T-C, Lin T-H, Yao T-Y, Huang C-H, Lee Y-J: TGF-beta inhibits prolactin-induced expression of beta-casein by a Smad3-dependent mechanism. J Cell Biochem 2008, 104:1647-1659.

77. Cocolakis E, Dai M, Drevet L, Ho J, Haines E, Ali S, Lebrun J-J: Smad signaling antagonizes STAT5-mediated gene transcription and mammary epithelial cell differentiation. J Biol Chem 2008, 283:1293-1307.

78. Wang Z, Li G, Tse W, Bunting KD: Conditional deletion of STAT5 in adult mouse hematopoietic stem cells causes loss of quiescence and permits efficient nonablative stem cell replacement. Blood 2009, 113:4856-4865.

79. Liu F, Kunter G, Krem MM, Eades WC, Cain JA, Tomasson MH, Hennighausen L, Link DC: Csf3r mutations in mice confer a strong clonal HSC advantage via activation of Stat5. J Clin Invest 2008, 118:946-955.

80. Yao Z, Cui Y, Watford WT, Bream JH, Yamaoka K, Hissong BD, Li D, Durum SK, Jiang Q, Bhandoola A, Hennighausen L, O'Shea JJ: Stat5a/b are essential for normal lymphoid development and differentiation. Proc Natl Acad Sci U SA 2006, 103:1000-1005

81. Liu S, Dontu G, Wicha M: Mammary stem cells, self-renewal pathways, and carcinogenesis. Breast Cancer Res 2005, 7:86-95

82. Ren S, Cai HR, Li M, Furth PA: Loss of Stat5a delays mammary cancer progression in a mouse model. Oncogene 2002, 21:4335-4339.

83. Sakamoto K, Triplett AA, Schuler LA, Wagner KU: Janus kinase 2 is required for the initiation but not maintenance of prolactin-induced mammary cancer. Oncogene 2010, 29:5359-5369.

84. Nevalainen MT, Xie J, Torhorst J, Bubendorf L, Haas P, Kononen J, Sauter G, Rui $\mathrm{H}$ : Signal transducer and activator of transcription- 5 activation and breast cancer prognosis. J Clin Oncol 2004, 22:2053-2060.

85. Cotarla I, Ren S, Zhang Y, Gehan E, Singh B, Furth PA: Stat5a is tyrosine phosphorylated and nuclear localized in a high proportion of human breast cancers. Int J Cancer 2004, 108:665-671.

86. Yamashita H, Nishio M, Ando Y, Zhang Z, Hamaguchi M, Mita K, Kobayashi S, Fujii Y, Iwase H: Stat5 expression predicts response to endocrine therapy and improves survival in estrogen receptor-positive breast cancer. Endocr Relat Cancer 2006, 13:885-893.

87. Peck AR, Witkiewicz AK, Liu C, Stringer GA, Klimowicz AC, Pequignot E, Freydin B, Tran TH, Yang N, Rosenberg AL, Hooke JA, Kovatich AJ, Nevalainen MT, Shriver CD, Hyslop T, Sauter G, Rimm DL, Magliocco AM, Rui H: Loss of nuclear localized and tyrosine phosphorylated stat5 in breast cancer predicts poor clinical outcome and increased risk of antiestrogen therapy failure. J Clin Oncol 2011, 29:2448-2458

88. Tran TH, Utama FE, Lin J, Yang N, Sjolund AB, Ryder A, Johnson KJ, Neilson LM, Liu C, Brill KL, Rosenberg AL, Witkiewicz AK, Rui H: Prolactin inhibits BCL6 expression in breast cancer through a Stat5a-dependent mechanism. Cancer Res 2010, 70:1711-1721.

89. Bogorad RL, Courtillot C, Mestayer C, Bernichtein S, Harutyunyan L, Jomain JB, Bachelot A, Kuttenn F, Kelly PA, Goffin V, Touraine P: Identification of a gainof-function mutation of the prolactin receptor in women with benign breast tumors. Proc Natl Acad Sci U S A 2008, 105:14533-14538.

90. Mohankumar KM, Perry JK, Kannan N, Kohno K, Gluckman PD, Emerald BS, Lobie PE: Transcriptional activation of signal transducer and activator of transcription (STAT) 3 and STAT5B partially mediate homeobox A1stimulated oncogenic transformation of the immortalized human mammary epithelial cell. Endocrinology 2008, 149:2219-2229.

91. Shi Z, Hodges VM, Dunlop EA, Percy MJ, Maxwell AP, El-Tanani M, Lappin TRJ: Erythropoietin-induced activation of the JAK2/STAT5, PI3K/Akt, and Ras/ ERK pathways promotes malignant cell behavior in a modified breast cancer cell line. Mol Cancer Res 2010, 8:615-626.

92. Sultan AS, Brim H, Sherif ZA: Co-overexpression of Janus kinase 2 and signal transducer and activator of transcription 5a promotes differentiation of mammary cancer cells through reversal of epithelial-mesenchymal transition. Cancer Sci 2008, 99:272-279.

93. Gutzman JH, Rugowski DE, Nikolai SE, Schuler LA: Stat5 activation inhibits prolactin-induced AP-1 activity: distinct prolactin-initiated signals in tumorigenesis dependent on cell context. Oncogene 2007, 26:6341-6348.

94. Barclay JL, Anderson ST, Waters MJ, Curlewis JD: SOCS3 as a tumor suppressor in breast cancer cells, and its regulation by PRL. Int J Cancer 2009 124:1756-1766.

95. Yuan T, Wang Y, Zhao ZJ, Gu H: Protein-tyrosine phosphatase PTPN9 negatively regulates ErbB2 and epidermal growth factor receptor signaling in breast cancer cells. J Biol Chem 2010, 285:14861-14870.

96. Perotti C, Liu R, Parusel CT, Böcher N, Schultz J, Bork P, Pfitzner E, Groner B, Shemanko CS: Heat shock protein-90-alpha, a prolactin-STAT5 target gene identified in breast cancer cells, is involved in apoptosis regulation. Breast Cancer Res 2008, 10:R94

97. Kim JK, Diehl JA: Nuclear cyclin D1: an oncogenic driver in human cancer. J Cell Physiol 2009, 220:292-296.

98. Sarfstein R, Maor S, Reizner N, Abramovitch S, Werner H: Transcriptional regulation of the insulin-like growth factor-I receptor gene in breast cancer. Mol Cell Endocrinol 2006, 252:241-246.

99. Ciocca DR, Gago FE, Fanelli MA, Calderwood SK: Co-expression of steroid receptors (estrogen receptor alpha and/or progesterone receptors) and Her-2/neu: clinical implications. J Steroid Biochem Mol Biol 2006, 102:32-40.

doi:10.1186/bcr2921

Cite this article as: Furth PA, et al:: Signal transducer and activator of transcription 5 as a key signaling pathway in normal mammary gland developmental biology and breast cancer. Breast Cancer Research 2011 $13: 220$. 